\title{
Malic Acid in Wine: Origin, Function and Metabolism during Vinification
}

\author{
H. Volschenk ${ }^{1 a}$, H.J.J. van Vuuren ${ }^{2}$ and M. Viljoen-Bloom ${ }^{1 *}$
}

(1) Department of Microbiology, Stellenbosch University, Private Bag X1, 7602 Matieland, South Africa

(2) Wine Research Centre, University of British Columbia, Vancouver, B.C. V6T 1Z4, Canada

(a) Current address: Department of Food and Agricultural Sciences, Cape Peninsula University of Technology, PO Box 652, 8000 Cape Town, South Africa

Submitted for publication: May 2006

Accepted for publication: September 2006

Key words: malic acid; wine; deacidification

\begin{abstract}
The production of quality wines requires a judicious balance between the sugar, acid and flavour components of wine. L-Malic and tartaric acids are the most prominent organic acids in wine and play a crucial role in the winemaking process, including the organoleptic quality and the physical, biochemical and microbial stability of wine. Deacidification of grape must and wine is often required for the production of well-balanced wines. Malolactic fermentation induced by the addition of malolactic starter cultures, regarded as the preferred method for naturally reducing wine acidity, efficiently decreases the acidic taste of wine, improves the microbial stability and modifies to some extent the organoleptic character of wine. However, the recurrent phenomenon of delayed or sluggish malolactic fermentation often causes interruption of cellar operations, while the malolactic fermentation is not always compatible with certain styles of wine. Commercial wine yeast strains of Saccharomyces are generally unable to degrade L-malic acid effectively in grape must during alcoholic fermentation, with relatively minor modifications in total acidity during vinification. Functional expression of the malolactic pathway genes, i.e. the malate transporter (mae1) of Schizosaccharomyces pombe and the malolactic enzyme (mleA) from Oenococcus oeni in wine yeasts, has paved the way for the construction of malate-degrading strains of Saccharomyces for commercial winemaking.
\end{abstract}

\section{INTRODUCTION}

Acidity in wine originates mainly from two sources. The first is the organic acids extracted from grapes into the must during harvesting and crushing; L-tartaric, L-malic and citric acids are the predominant acids (Boulton et al., 1996). The chemical composition of harvested grapes therefore strongly influences the composition of must at the onset of vinification and ultimately the final quality of the bottled wine. Secondly, the combined metabolism of yeasts and bacteria during subsequent fermentation steps contributes to the pool of wine acids. The net contribution of these microorganisms to wine acidity is the sum of both the degradation of some grape acids and the biosynthesis of some unique organic acids by yeasts and bacteria during and after alcoholic fermentation. Succinic acid is the major acid produced by yeast during fermentation. Lower levels of other tricarboxylic acid (TCA) cycle intermediates are also present (Ribéreau-Gayon et al., 2000). Lactic acid is mainly produced by lactic acid bacteria (LAB) during malolactic fermentation, but small amounts can also be synthesised by yeast. Several cellar procedures such as maceration and cold stabilisation also influence the final acid composition of wine due to precipitation phenomena (Jackson and Schuster, 1997).

The conversion of grape sugars to ethanol and carbon dioxide is often described as the fundamental biochemical reaction involved in winemaking, but an intricate ensemble of biological and spontaneous chemical reactions all contribute to the final product. Besides the importance of flavour compounds, the presence or absence of organic acids in wine plays a pivotal role in the production of quality wines. Acidity in wine directly or indirectly affects several different levels of the winemaking process and ultimately determines wine quality in terms of the perceived organoleptic and aesthetic character. Wine acidity also influences the ageing potential or the shelf-life of wine, as it determines the physical, biochemical and microbial stability of wine. In addition, wine acidity and $\mathrm{pH}$ affect the timely succession of cellar events and the effectiveness of several techniques applied by winemakers (Margalit, 1997).

Winemakers often experience problems when some wine acids exceed acceptable concentration levels. Since the artificial manipulation of sugars and flavourants in wine is detrimental to wine quality and prohibited in most wine producing countries, winemakers can only modify the acidity component of wine by adding or removing certain acids. The adjustment of acidity in must or wine is complex and a number of factors must be taken into account to ensure the correct method and timing for rectifying wine acidity. Winemakers routinely employ bacterial malolactic fermentation to deacidify wine (Henick-Kling, 1993). Although this step is considered the most natural method for wine acidity adjustment, which also contributes to microbial stability and organoleptic complexity, there are a number of pitfalls associated with this biological process.

This review discusses, with special reference to L-malic acid, the origin and evolution of organic acids in grapes and wine, the role of acidity in wine and the fate of these organic acids during fermentation and downstream processing. 


\section{ORGANIC ACIDS IN GRAPES}

The principal organic acids in grapes are L-tartaric and L-malic acid (see Table 1), accounting for more than $90 \%$ of the grape berry's acid content (Boulton et al., 1996). Although L-malic and L-tartaric acids have similar chemical structures, they are synthesised from glucose via different metabolic pathways in grape berries. L-Malic acid is formed via glycolysis and the TCA cycle, while ascorbic acid is the principle intermediary product of L-tartaric acid biosynthesis. Slight differences in grape acidity among different grape varieties are usually found, affecting especially the ratio between L-tartaric acid and L-malic acid in different grape cultivars (Kliewer et al., 1967). L-Tartaric acid is usually present in grapes at average concentrations of 5 to $10 \mathrm{~g} / \mathrm{L}$ (Ruffner, 1982), while mature grapes contain between 2 and 6.5 g/L L-malic acid (Boulton et al., 1996; Ribéreau-Gayon et al., 2000). Excessive amounts of malic acid (15 to $16 \mathrm{~g} / \mathrm{L}$ ) may be present in grapes harvested during exceptionally cold summers in the cool-climate viticultural regions of the world (Gallander, 1977). Although tartaric acid is often found at higher concentrations than L-malic acid and is the stronger acid of the two, its concentration is relatively constant. It is the fluctuating concentration of L-malic acid that usually poses problems to winemakers (Margalit, 1997).

\section{Evolution of L-malic acid during grape berry development}

The development of the grape berry displays a double-sigmoidal growth pattern (Kanellis and Roubelakis-Angelakis, 1996), characterised by three successive phases: Phase I is the green or herbaceous stage immediately after flowering (see Fig. 1). The berries are hard and green, and undergo a short period of cell division and cell enlargement resulting in rapid expansion of the berry (Kanellis and Roubelakis-Angelakis, 1996; Terrier et al., 2001). Characteristic of Stage I is the increase in vacuolar size of the grape berry cells due to the rapid storage of L-malic and L-tartaric acid (Fillion et al., 1999; Pratelli et al., 2002). Stage II comprises a short lag phase during which berry growth ceases and berry acidity reaches a maximum due to the continued accumula- tion of L-malic and L-tartaric acid. Following the lag phase, there is a second period of 'berry growth' (Stage III). The entry into Stage III begins with the sudden onset of ripening or "véraison", which generally starts between 6 to 8 weeks after flowering and lasts for 35 to 55 days depending on the grape cultivar (Coombe, 1992; Pratelli et al., 2002; Ribéreau-Gayon et al., 2000).

Véraison, which seems to be a stress-associated process, is characterised by several drastic physical and biochemical changes in the grape berry (Coombe, 1992; Davies and Robinson, 2000). The second most significant biochemical change during véraison is the rapid reduction of grape berry acidity, which coincides with the change in sugar composition of the grape berry. Grape berries respire actively during the early stages of growth, but the intensity of respiration slows down as they advance in age. During véraison, the availability of the respiratory substrate, sucrose (via photosynthesis), becomes limited due to the degradation of chlorophyll. The berry is therefore forced to shift its metabolism from sugar to L-malic acid respiration. Prior to the onset of véraison, L-malic acid is the most abundant organic acid (up to $25 \mathrm{~g} / \mathrm{L}$ ) in the grape berry vacuole, resulting in the low internal $\mathrm{pH}$ of 2.5 of grapes (Ruffner, 1982; Ribéreau-Gayon et $a l ., 2000)$. With the onset of veraison, the L-malic acid concentration rapidly decreases to between 4 and $6.5 \mathrm{~g} / \mathrm{L}$, or even as low as 1 to $2 \mathrm{~g} / \mathrm{L}$, with a concomitant increase in internal berry $\mathrm{pH}$ (pH of ca. 3.5).

The biochemistry related to the accumulation and rapid respiration of L-malic acid in grapes has been studied in detail (see Fig. 2). L-Malic acid accumulates in the berry vacuole before véraison (Stages I and II, see Fig. 2) via the collective activities of the phosphoenolpyruvate carboxylase (PEPC) and malate dehydrogenase (MDH) enzymes (Blanke and Lenz, 1989; Diakou et al., 2000; Or et al., 2000). The cytosolic PEPC enzyme, well known for its photosynthetic role in $\mathrm{C}_{4^{-}}$and CAM-plants, catalyses the $\beta$-carboxylation of phosphoenolpyruvic acid to yield oxaloacetic acid and inorganic phosphate. The resulting oxaloacetic acid is further reduced by the NAD-dependent malate

\section{TABLE 1}

Organic acids present in grapes and wine (Boulton et al., 1996).

\begin{tabular}{|c|c|c|c|}
\hline \multicolumn{2}{|c|}{ Fixed acids } & \multicolumn{2}{|c|}{ Volatile acids } \\
\hline $\begin{array}{l}\text { L-tartaric acid }(5-10 \mathrm{~g} / \mathrm{L}) \\
\text { L-malic acid* }(2-6.5 \mathrm{~g} / \mathrm{L}) \\
\text { L-lactic acid }(1-3 \mathrm{~g} / \mathrm{L}) \\
\text { citric acid** }(0.5-1 \mathrm{~g} / \mathrm{L}) \\
\text { succinic acid }(0.5-1.5 \mathrm{~g} / \mathrm{L}) \\
\text { amino acids }\end{array}$ & $\begin{array}{l}\text { pyruvic acid } \\
\alpha \text {-ketoglutaric acid } \\
\text { isocitric acid } \\
\text { 2-oxoglutaric acid } \\
\text { dimethyl glyceric acid } \\
\text { citramalic acid } \\
\text { gluconic acid*** } \\
\text { galacturonic acid } \\
\text { glucuronic acid } \\
\text { mucic acid } \\
\text { coumaric acid } \\
\text { ascorbic acid }\end{array}$ & acetic acid & $\begin{array}{l}\text { formic acid } \\
\text { propionic acid } \\
\text { 2-methylpropionic acid } \\
\text { butyric acid } \\
\text { 2-methylbutyric acid } \\
\text { 3-methylbutyric acid } \\
\text { hexanoic acid } \\
\text { octanoic acid } \\
\text { decanoic acid }\end{array}$ \\
\hline
\end{tabular}

*15 -16 g/L L-malic acid has been reported in cool climate regions

** $>0.3 \mathrm{~g} / \mathrm{L}$ when wines are stabilised for metal precipitation

***present in wine with Botrytis cinerae infection 


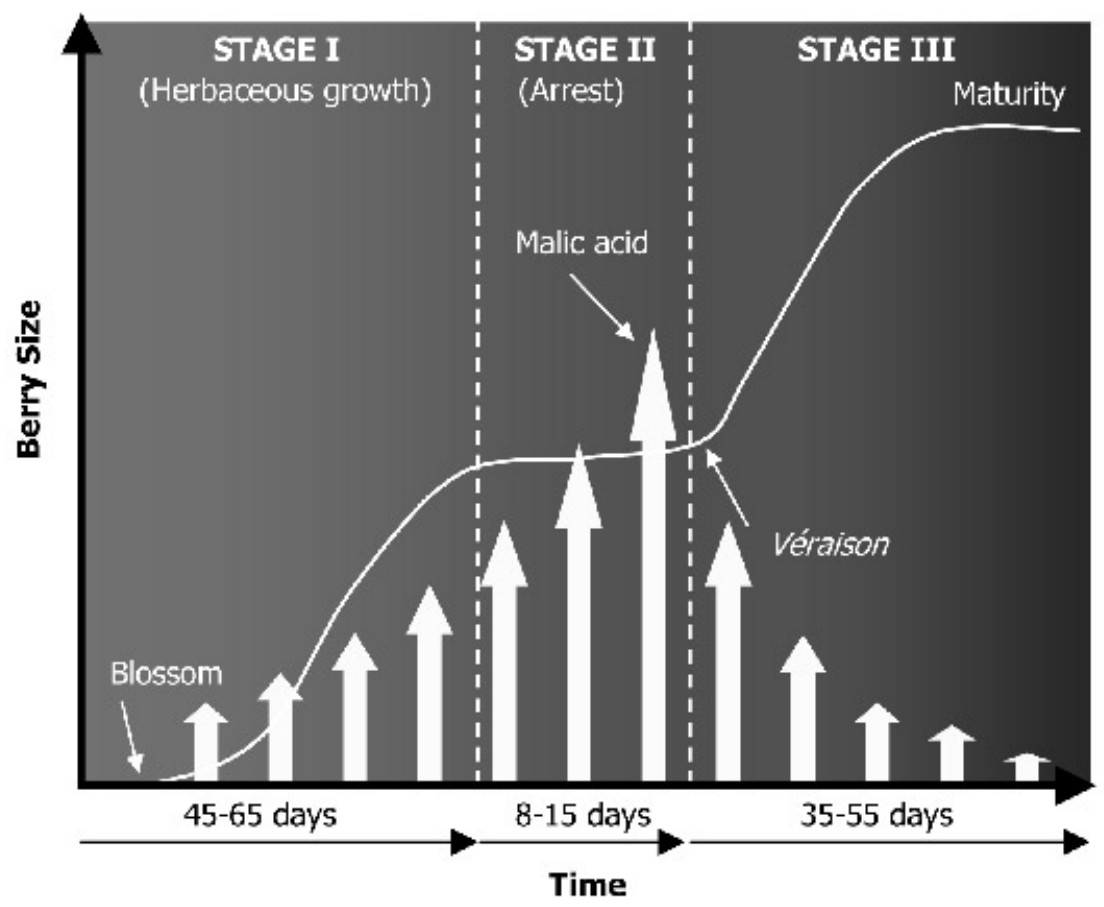

FIGURE 1

The double-sigmoid model of grape berry development indicates the three stages of herbaceous growth, temporary growth arrest and véraison (adapted from Jackson and Schuster, 1997). The thick arrows denote the simultaneous pattern of L-malic acid synthesis and accumulation as well as rapid decrease via respiration during grape berry development.

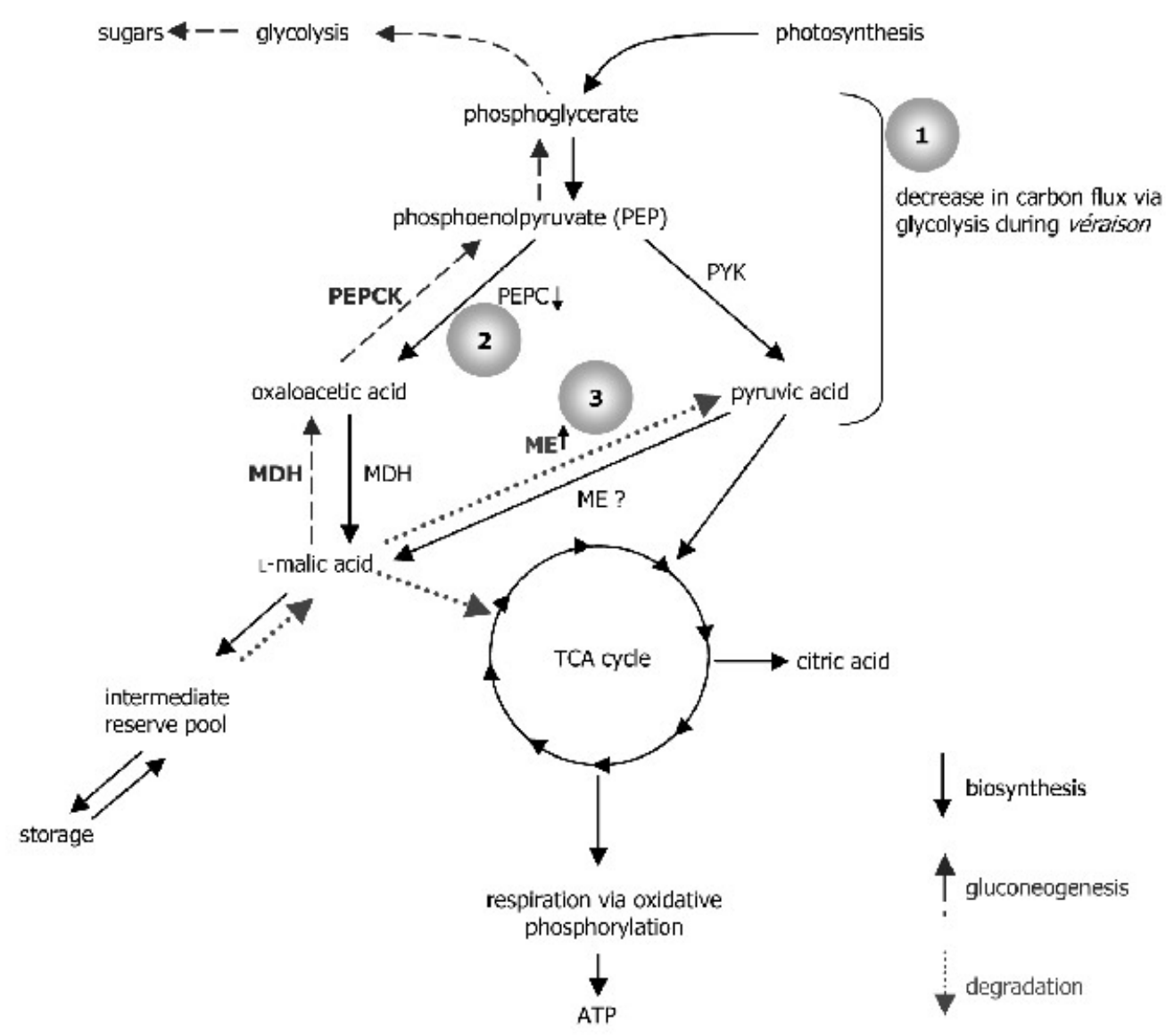

FIGURE 2

The biochemical pathways involved in the biosynthesis, dissipation and regulation of L-malic acid in grape berries (adapted from Kanellis and Roubelakis-Angelakis, 1996).). $\mathrm{ME}=$ malic enzyme; $\mathrm{PEPC}=$ phosphoenolpyruvate carboxylase; $\mathrm{PEPCK}=$ phosphoenolpyruvate carboxykinase; $\mathrm{MDH}=$ malate dehydrogenase. The decrease in L-malic acid is due to (1) a decrease in carbon flux via glycolysis, (2) a decrease in L-malic acid biosynthesis via PEPC, and (3) an increase in L-malic acid respiration via the malic enzyme. 
dehydrogenase to produce L-malic acid. Oxaloacetic acid and L-malic acid can enter the TCA cycle to produce citrate as well as other metabolites (Diakou et al., 2000). The $\beta$-carboxylation of phosphoenolpyruvic acid plays an important role as an anapleurotic $\mathrm{CO}_{2}$ fixation step that supplies carbon skeletons for other cellular processes such as osmolarity regulation, $\mathrm{pH}$ regulation and nitrogen assimilation (Diakou et al., 2000). Although a high malic enzyme (ME) activity during the accumulation phase of malic acid has been noted, the actual contribution to L-malic acid concentration via the reverse malic enzyme reaction, i.e. pyruvic acid carboxylation, was found to be insignificant (Ruffner et al., 1984; Kanellis and Roubelakis-Angelakis, 1996).

The rapid decrease in L-malic acid concentration inside the grape berry during véraison is the result of a significant decrease in L-malic acid biosynthesis synchronised with a sharp increase in L-malic acid degradation via respiration. Initially the concentration of L-malic acid in the berry vacuole is diluted due to the influx of water during berry expansion in the second growth phase (Stage III, see Fig. 1). Secondly, the slowing down of glycolytic carbon flow during véraison results in the increase of glucose and fructose in the berry vacuole, and also a decrease in L-malic acid synthesis via pyruvic acid in the tricarboxylic acid (TCA) cycle. The biosynthesis of L-malic acid via the PEPC enzyme is also reduced due to a lack of PEPC gene transcription, which correlates with the start of véraison (Or et al., 2000).

The rate of respiration of stored L-malic acid significantly increases during véraison due to a higher demand for respiratory substrates in the grape berry. L-Malic acid is degraded in grape berries via two pathways, mainly by the cytosolic NADP-malic enzyme (ME) (Ruffner et al., 1984) and, to a lesser extent, by the PEP carboxykinase (PEPCK) (see Fig. 2) (Ruffner and Kliewer, 1975). There is also evidence that the malate dehydrogenase (MDH), especially the mitochondrial iso-enzyme, plays a putative role in the degradation of L-malic acid in the grape berry. Gene expression profiles and enzyme activities of the ME and $\mathrm{MDH}$ enzymes increase at the onset of véraison, descriptive of the rapid depletion scenario of L-malic acid (Or et al., 2000). L-Malic acid degraded via the NADP-malic enzyme fuels the required biosynthetic (in particular the provision of NADPH) and respiratory pathways (Ruffner et al., 1984), whereas a small percentage of L-malic acid $(<5 \%)$ is converted back to phosphoenolpyruvate via MDH and PEPCK for glucose synthesis via gluconeogenesis (see Fig. 2) (Ruffner and Kliewer, 1975; Ruffner, 1982; Kanellis and Roubelakis-Angelakis, 1996 ).

\section{Environmental factors: Warm climate vs. cool climate}

Acidity in wine is a function of various exogenous factors, such as the climate or average temperature, the grape cultivar and vineyard practices (Beelman and Gallander, 1979; Ribéreau-Gayon et al., 2000; Zoecklein et al., 1995). The most important factors that influences the final sugar:organic acid and the malic:tartaric acid ratios in grapes is the prevailing climatic conditions and ambient temperature during Stage III of berry ripening (Crippen and Morrison, 1986; Kanellis and Roubelakis-Angelakis, 1996; Ruffner, 1982; Zoecklein et al., 1995;).

Cool-climate regions, which include parts of northern Europe, Canada and northeast USA, are characterised by shorter ripening periods and/or sub-optimal mean temperatures $\left(9^{\circ} \mathrm{C}\right.$ to $\left.15^{\circ} \mathrm{C}\right)$ dur- ing the late ripening season (Jackson, 2001). The rate of respiration of L-malic acid is significantly slower in cold climates, resulting in "immature grapes" at harvesting, containing a high titratable acidity (TA) content and low $\mathrm{pH}$. High acidity in cool-climate grapes can be exasperated by unusually cold seasons, poor vineyard locations, sub-optimal cultivar selections or poor viticultural practices such as overcropping. In these countries, L-malic acid can comprise up to $50 \%$ of the total acidity in grapes.

In contrast, the warm climates, including parts of southern Europe, California, South Africa and Australia, have longer ripening seasons and/or higher mean temperatures $\left(16^{\circ} \mathrm{C}\right.$ and above) (Pretorius, 2000). Since the prevailing temperature of the region directly influences the rate of L-malic acid respiration in grapes, grapes in the warmer climates tend to have a faster rate of L-malic acid respiration compared to those of the cooler climates. Thus, grapes from the warmer climates often contain insufficient final TA values and do not meet desirable $\mathrm{pH}$ values at harvest time.

\section{THE ROLE OF MALIC ACID IN WINE}

Organic acids can contribute positively to the organoleptic character of wine when in balance with the other wine components. The sour-sweet balance is well known as a required sensory quality in wine, especially in white wine (Burns and Noble, 1985; Fischer and Noble, 1994; Martin and Revel, 1999; Vannier et al., 1999). Acid-balanced wines are usually perceived as having refreshing or crisp sensory undertones, while descriptions such as "sharp", "green", "acidulous" or "unripe" often refer to wine with too much acidity. When present in excessive concentrations, organic acids leave a uniquely tart or sour taste, indicative of the specific acid in wine. For example, excess quantities of L-malic acid are perceived as a sour taste, resembling that of unripe apples. Furthermore, wine acidity often disguises or accentuates the perception of other wine tastes; it usually masks excess sweetness, while the perception of astringency is emphasised when coinciding with low $\mathrm{pH}$ values (Noble, 1998).

The specific organic acid composition of wine determines the specific $\mathrm{pH}$ of the wine, which in turn indirectly influences the perception of taste in wine. Since the $\mathrm{pH}$ of any given solution is based on the balance between the protonated and deprotonated isoforms of organic molecules, the $\mathrm{pH}$ of wine determines the degree of organic acid and amino acid ionisation in a wine solution. The level of ionisation of these organic building blocks influences the ionic state, solubility and biological activity of many complex molecules such as proteins, fatty acids, phenolic compounds, etc. It is thus conceivable that a minor change in wine $\mathrm{pH}$ (as small as 0.05 units), when coinciding with changes in total acidity (TA) of 0.2 to $0.5 \mathrm{~g} / \mathrm{L}$, significantly influences the organoleptic perception of wine (Margalit, 1997).

Organic acids and $\mathrm{pH}$ also play important roles in the development of specific flavour compounds during vinification. A high TA and low $\mathrm{pH}$ in grape must has been linked to the release of floral aroma and other flavour precursors from grape skins during the crushing stages of vinification. The release of stored organic acids, specifically L-malic acid and tartaric acid, from the grape berry during crushing is responsible for acid hydrolysis of nonvolatile flavour compounds like monoterpene glycosides, some phenolic compounds, $\mathrm{C}_{13}$-norisoprenoids, benzyl alcohol and 2phenylethanol from the berry. These flavour compounds are 
essential for the development of a healthy, complex flavour profile during vinification and subsequent ageing of wine (Strauss et al., 1987; Winterhalter et al., 1990). Acidity in wine, and more specifically wine $\mathrm{pH}$, plays an important role in the preservation of wine aroma and flavour, as the $\mathrm{pH}$ of wine influences the rate of oxidation in wine. A low $\mathrm{pH}$ in must or wine safeguards wine and prevents or delays phenolic oxidation by maintaining the phenolic compounds in their non-ionised state, rendering them less susceptible to oxidation.

The acidity and $\mathrm{pH}$ of wine also influences the visible attributes of wine, such as wine colour and clarity. The colour of white wine is usually affected by $\mathrm{pH}$-dependent phenolic oxidation reactions that lead to browning of the wine colour. In red wines, low $\mathrm{pH}$ and free sulphur dioxide are essential for the development and stability of the red colour, which can be ascribed to anthocyanins (Margalit, 1997). Furthermore, the $\mathrm{pH}$ of red wine also influences the degree of co-pigmentation of anthocyanins, which in turn determines the red colour density. Furthermore, wine clarity can be affected by the undesirable precipitation of acids, particularly tartaric acid, which can be considered an aesthetic imperfection, especially in young bottled wines. Excess tartaric acid is routinely removed before bottling by cold stabilisation and racking or filtering of potassium bitartrate crystals.

Wine acidity, but more importantly wine $\mathrm{pH}$, has a profound effect on the microbial stability of wine as it determines the survival and proliferation of bacteria and yeast species during and after vinification. Grape must or juice with a low $\mathrm{pH}(<3.5)$ is usually more protected against microbial spoilage at the onset of alcoholic fermentation, as the low $\mathrm{pH}$ is not conducive to the growth of most spoilage bacteria and yeast species, but still permits the proliferation of the wine yeast $S$. cerevisiae (Capucho and San Romao, 1994).

Extreme $\mathrm{pH}$ values in wine usually have an adverse effect on the growth of yeast and bacteria during vinification, i.e. at $\mathrm{pH}$ values below 2.9 the growth of spoilage bacteria and yeasts, as well as most strains of $S$. cerevisiae will be inhibited. This may delay the onset of alcoholic fermentation and affect the success of inoculating with LAB starter cultures after alcoholic fermentation (Charoenchai et al., 1998). When the $\mathrm{pH}$ of must or juice exceeds $\mathrm{pH} 3.5$, the risk of overgrowth of spoilage lactobacilli, pediococci and strains of Oenococcus oeni during alcoholic fermentation is increased. At elevated $\mathrm{pH}$ ranges, strains of these LAB can rapidly proliferate to substantial populations before the actual onset of alcoholic fermentation. Premature growth of LAB poses a serious risk to wine quality, since glucose is fermented to lactic acid and acetic acid, resulting in elevated volatile acidity levels in wine, reduced ethanol yields as well as stuck or sluggish alcoholic fermentation (Fugelsang, 1997; Narendranath et al., 1997).

Lastly, TA and $\mathrm{pH}$ also influence several winemaking operations. For example, the requirement for chemical additives is reduced in low $\mathrm{pH}$ wines. Wines with low $\mathrm{pH}$ values require lower concentrations of $\mathrm{SO}_{2}$ due to the added protection against oxidation and microbial spoilage supplied by the low $\mathrm{pH}$. The effective precipitation of pectins and heat-sensitive proteins during bentonite treatment is also enhanced by a lower $\mathrm{pH}$. Since less bentonite is required at lower $\mathrm{pH}$ values for the effective removal of solids and proteins during racking, the loss of flavour compounds is minimised (Boulton et al., 1996; Margalit, 1997; Ribéreau-Gayon et al., 2000).
PHYSICOCHEMICAL METHODS FOR ACIDITY ADJUSTMENT IN WINE

Acidity adjustment in grape must is an essential step during vinification when the TA and/or $\mathrm{pH}$ of the must or wine exceed acceptable ranges. As a rule, the TA of wine increases by 1 to 2 $\mathrm{g} / \mathrm{L}$ during alcoholic fermentation via the production of L-malic, succinic, acetic and lactic acids by strains of yeast and bacteria. However, significant variations might occur due to the contribution of specific yeast strains used for alcoholic fermentation and the success of the malolactic fermentation.

Several factors need to be considered to determine the timing (before or after alcoholic fermentation) and method of rectifying wine acidity, which are generally based on the initial $\mathrm{pH}$ of the must or juice. Traditionally, acidification of low-acid (high $\mathrm{pH}$ ) grape must in warm viticultural regions is preferably done before the start of alcoholic fermentation. Reducing the $\mathrm{pH}$ is conducive to the development of optimal wine flavour during fermentation and prevents the proliferation of spoilage lactobacilli and pediococci during alcoholic fermentation. Similarly, a reduction of TA prior to fermentation is a prerequisite in grape must with a $\mathrm{pH}$ below 2.9 , since the onset of alcoholic fermentation by strains of Saccharomyces will be negatively affected at such low $\mathrm{pH}$ extremes.

Viticulturists have several vineyard practices available to preserve or decrease the acidity of grapes. Winemakers in the warmclimate countries, for example, can alleviate the problem of low acidity wines by selecting specific cultivars with a natural higher tartaric:malic acid ratio, such as Semillon and Riesling (Lavee and Nir, 1986). In contrast, Cabernet Sauvignon is classified as an intermediate-acidity variety (Kliewer et al., 1967) that will relieve high acidity problems to a limited degree in the cool-climate regions. Canopy management, irrigation control and soil fertilisation have a significant influence on the acid composition of grapes. For example, nitrogen and potassium fertilisation stimulates the accumulation of L-malic acid due to increased foliage and shading in bunches. Berries maturing in densely shaded canopy interiors are generally associated with higher TA levels due to an increase in L-malic acid (Archer and Strauss, 1989; Morrison and Noble, 1990; Smart, 1985; Zoecklein et al., 1995). Similarly, viticulturists in the cool-climate regions can use trellising and leafpruning techniques, which allows grape bunches to be more exposed to sunlight and increase the microclimate temperature to ensure increased respiration of L-malic acid during véraison.

Several cellar operations influence the TA and $\mathrm{pH}$ of wine. Skin contact or maceration generally leads to a slight decrease in TA and an increase in $\mathrm{pH}$ in the must before the start of fermentation (Darias-Martin et al., 2000; Ferreira et al., 1995). Skin contact is often applied in red wines (and some white wines) to extract anthocyanins and other phenolic flavour compounds from the pomace to ensure the optimal colour and flavour development in red wines. However, increased extraction of potassium from the skins coincides with phenolic extraction during skin contact, which normally causes an increase in potassium bitartrate precipitation. Grape acidity can also be reduced by carbonic maceration, a maceration process in which the grapes are kept under anaerobic conditions by exposing them to $\mathrm{CO}_{2}$ gas before crushing or pressing. In this anaerobic environment, certain intracellular fermentation reactions are stimulated in the intact berries, one of which is the oxidative decarboxylation of L-malic acid to pyru- 
vic acid, catalysed by a berry NADP-dependent malic enzyme (EC 1.1.1.40) (Beelman and Gallander, 1979).

\section{Acidification of low-acid wines}

Several artificial methods for acidification of grape must are available to winemakers, the most traditional method of which is the use of raw gypsum or plaster (hydrous calcium sulphate), which reacts with potassium bitartrate and releases free tartaric acid. This method is seldom applied in modern winemaking due to the risk of increased hydrogen sulphide production by yeast during fermentation (Zoecklein et al., 1995). Acidification of wine can also be achieved by adding naturally occurring grape acids to wine, such as tartaric, D/L-malic, citric or fumaric acid. Although succinic acid is relatively resistant to microbial attack under fermentative conditions, it cannot be utilised as an acidulating agent due to its bitter-salty taste (Ribéreau-Gayon et al., 2000).

Tartaric acid is the preferred acidulating agent in low-acid wines; it is relatively more resistant to microbial breakdown and can thus be added before the onset of alcoholic fermentation without the risk of off-flavours. Acidification of grape must with L-malic acid and citric acid can be applied with some degree of success, but degradation of these acids by spoilage LAB poses a risk under winemaking conditions. L-Malic acid does not precipitate like tartaric acid, but can initiate a second round of malolactic fermentation if still present in the wine just before bottling. As a precaution, malic acid is added as a racemic mixture of D/L-malic acid to the must at the beginning of fermentation, which leads to increased TA and lower $\mathrm{pH}$ of the wine. The risk of bottled malolactic fermentation is significantly reduced, since most or all of the L-malic acid is removed by the first round of malolactic fermentation, leaving only the D-malic acid isoform that is resistant to microbial attack, and maintains a low $\mathrm{pH}$.

\section{Deacidification of high-acid wines}

In cool viticultural regions, the removal of tartaric acid or excess L-malic acid from the wine before or after alcoholic fermentation is usually required to ensure wines with a balanced acid content and sufficient stability. Deacidification of high-acid wines can be achieved through physicochemical methods such as blending, chemical neutralisation and precipitation, or by biological means through the microbial degradation of L-malic acid, as will be discussed in a following section.

Blending of grape musts with different TA and $\mathrm{pH}$ indexes is one of the most elementary and effective solutions available to winemakers. However, blending of a low-pH must with a high$\mathrm{pH}$ must to neutralise the $\mathrm{pH}$ before fermentation is not always practically achievable due to the lack of available musts with significantly opposite characteristics in the same wine-producing region. Another physical method employed to decrease the TA of high-acid musts is the process of amelioration (Kluba and Beelman, 1975), which involves the dilution of grape must with water to reduce the must TA before fermentation. Amelioration, however, has become an unacceptable winemaking practice due to its detrimental effect on wine flavour, aroma, body and colour (especially in red wines) (Margalit, 1997).

Acids become less soluble and their salts precipitate in wine under chilled conditions and increased ethanol concentrations. The TA of wine or grape must can therefore be reduced by pre- cipitating tartaric acid and, to a lesser extent, L-malic acid salts. Tartaric acid usually precipitates in wine at the end of fermentation as potassium bitartrate crystals. To prevent the formation of tartaric acid crystals during wine ageing, cold stabilisation is applied to promote tartaric acid crystallisation and precipitation. Removal of the tartaric acid crystals during subsequent racking, filtration or centrifugation leads to a lower tartaric acid concentration, and thus a decrease in TA and an increase in $\mathrm{pH}$. Potassium bicarbonate $\left(\mathrm{KHCO}_{3}\right)$ and calcium carbonate $\left(\mathrm{CaCO}_{3}\right)$ can be added to wine to assist in tartaric acid precipitation, but L-malic acid is unaffected, often leading to undesirable tartaric:malic acid ratios in wine (Ribéreau-Gayon et al., 2000).

An effective method to reduce the TA of high-acid grape musts before fermentation is double salt-precipitation treatment (also known as Acidex or DICALCIC treatment) (Ribéreau-Gayon et al., 2000). This method is used in cool climate regions and is based on the addition of a fine powder of calcium carbonate that contains a $1 \%$ calcium tartaric and malic acid salt mixture as a seeding agent. At $\mathrm{pH}$ values above 4.5 this additive causes the precipitation of supposedly equimolar quantities of both tartaric and L-malic acid. Usually, a pre-determined fraction of the wine is treated with Acidex and then blended back with the untreated wine to yield a wine with a lower TA and higher $\mathrm{pH}$.

\section{BIOLOGICAL DEACIDIFICATION VIA MALOLACTIC FER- MENTATION}

Since the physicochemical deacidification of wine is often timeconsuming, requires increased labour and capital input, and is regularly associated with reduced wine quality (Pretorius, 2000), biological deacidification of wine with LAB is the traditional method of choice for the removal of excess wine acidity. During alcoholic fermentation, wine yeast strains convert the grape sugars, glucose and fructose into ethanol and various flavour compounds. Once all of the sugars are depleted, the yeast population rapidly declines, followed by the proliferation of LAB that utilise the remaining hexose and pentose sugars and performs malolactic fermentation (MLF). Modern winemaking has harnessed the benefits of the naturally occurring $\mathrm{LAB}$ in wine by developing pure starter cultures of selected LAB for improved efficiency and reliability of malolactic fermentation.

Various strains of LAB are regularly associated with different food and beverage-related biotopes such as wine, beer, ciders, vegetables, silage, bread (sourdough), cocoa and coffee fermentations (Hashizume and Mori, 1990; Henick-Kling, 1993) (Table 2). As the name suggests, strains of LAB have the ability to produce significant quantities of lactic acid from sugars. This is achieved either via a homofermentative metabolic pathway when only lactic acid is produced from glucose, or via a heterofermentative pathway when glucose is fermented to lactic acid, ethanol and acetic acid. Several strains of LAB, classified in Oenococcus, Leuconostoc, Weissella, Pediococcus and Lactobacillus genera, have the additional ability to convert L-malic acid into L-lactic acid and $\mathrm{CO}_{2}$ by means of the malolactic enzyme (see Fig. 3). The malolactic enzyme catalyses the conversion of L-malic acid to L-lactic acid in the presence of the cofactors $\mathrm{NAD}^{+}$and $\mathrm{Mg}^{2+}$ (Bony et al., 1997).

Wine LAB have a complex ecology, but are usually present in low numbers $\left(10^{2}-10^{4}\right.$ colony-forming units $\left.(\mathrm{CFU}) / \mathrm{g}\right)$ on grapes 
TABLE 2

Lactic acid bacteria isolated from wine (Carr et al., 2002; Du Plessis et al., 2004).

\begin{tabular}{|c|c|}
\hline Genus & Wine-related species \\
\hline Oenococcus & O. oeni (formerly Leuconostoc oenos) \\
\hline Leuconostoc & L. mesenteroides \\
\hline Lactobacillus & $\begin{array}{l}\text { Lb. plantarum, Lb. sakei, Lb. fructivorans (formerly trichodes), Lb. buchneri, Lb. fermentum, Lb. casei, Lb. homohiochii, } \\
\text { Lb. fructosus, Lb. desidiousis (reclassified as Lb. kefir), Lb. brevis, Lb. hilgardii, Lb. curvatus, Lb. delbrueckii, Lb. jensenii, } \\
\text { Lb. kunkeei, Lb. nagelii, Lb. paracasei, Lb. vermiforme, Lb. vini, Lb. yamanasheinsis, Lb. homohiochii, }\end{array}$ \\
\hline Pediococcus & P. damnosus (formerly P. cerevisiae), $P$. parvulus, $P$. pentosaceus \\
\hline
\end{tabular}

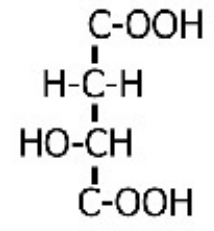

L(-) -Malic acid

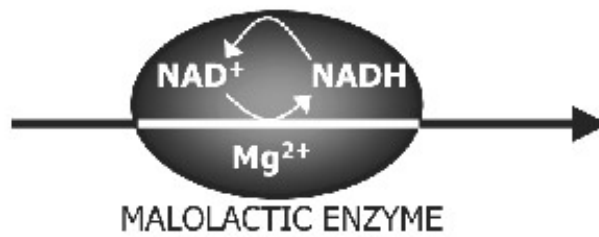

(MLE)

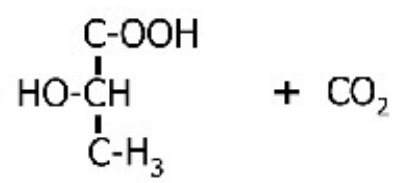

L(+) -Lactic acid

FIGURE 3

The NAD-dependent malolactic enzyme (MLE) transforms the $\mathrm{C}_{4}$ dicarboxylic acid L-malic acid to the $\mathrm{C}_{3}$ monocarboxylic acid L-lactic acid without any free intermediates. The conversion is a direct decarboxylation of L(-)-malic acid to L(+)-lactic acid and carbon dioxide (Pilone and Kunkee, 1970).

and in grape must at the early stages of vinification (Fugelsang, 1997; Lafon-Lafourcade et al., 1983; Lonvaud-Funel, 1999; Wibowo et al., 1985). The prevalence of LAB in grape musts is mainly correlated to the must $\mathrm{pH}$; an increase in $\mathrm{pH}(\mathrm{pH}>3.5)$ leads to a higher total number of LAB. However, elevated populations of LAB can also be found in musts from damaged grapes (Lonvaud-Funel, 1999). There are mainly four different genera of $\mathrm{LAB}$ present in the must at the beginning of vinification (see Table 2), i.e. Oenococcus, Lactobacilllus, Pediococcus and Leuconostoc (Dicks et al., 1990; Dicks and Van Vuuren, 1988; Fugelsang, 1997; Lonvaud-Funel, 1999; Wibowo et al., 1985).

During the early days of yeast alcoholic fermentation, the LAB population increases to ca. $10^{4} \mathrm{CFU} / \mathrm{mL}$, but quickly declines to only a few cells $/ \mathrm{mL}$ with the onset of ethanol production (Van Vuuren and Dicks, 1993; Fugelsang, 1997). The decline in LAB population is ascribed to a combination of low initial $\mathrm{pH}$ values, low temperatures, increased ethanol concentration, competitive interactions with yeasts, possible bacteriophage infections, as well as high concentrations of $\mathrm{SO}_{2}$. At the end of alcoholic fermentation, mainly strains of $O$. oeni proliferate to a population of $10^{7} \mathrm{CFU} / \mathrm{mL}$, which coincides with malolactic fermentation (Costello et al., 1983; Fleet et al., 1984; Lonvaud-Funel, 1999; Wibowo et al., 1985). Strains of $O$. oeni have the unique ability to survive in a wine milieu at $\mathrm{pH}$ values lower than 4.2 and ethanol levels as high as 10\% (v/v) (Garvie and Farrow, 1980). Strains of Pediococcus and Lactobacillus only proliferate in wines with initial high $\mathrm{pH}$ levels prior to or during alcoholic fermentation, and usually cause spoilage or sluggish alcoholic fermentations in wines (Costello et al., 1983; Fugelsang, 1997).

\section{Advantages and disadvantages of bacterial malolactic fer- mentation}

Malolactic fermentation is the preferred deacidification method used in most of the wine regions of the world. Red wine produc- tion in both cold- and warm-climate regions usually involves bacterial malolactic fermentation, naturally or induced, after yeast alcoholic fermentation. Natural malolactic fermentation occurs less frequently in white wines due to an average lower $\mathrm{pH}$ of most white cultivars and higher concentrations of $\mathrm{SO}_{2}$ employed (Rodriquez et al., 1990), but it can be induced with LAB starter cultures in some styles of wine, e.g. Chardonnay. The malolactic fermentation is crucial in the Champagne wine region of France, where the traditional méthode champenoise process is used to produce sparkling wine. The grapes used during the production of base wines are usually high in acid content and require the malolactic fermentation as a primary fermentation to deacidify and mature the base wine prior to the yeast fermentation in the bottle (Pool and Henick-Kling, 1991).

The malolactic fermentation affects four different, but interrelated, aspects of wine quality: wine acidity, microbial stability, sensory complexity and the hygienic quality of wine. Under certain conditions, the contributions made by malolactic fermentation improve wine quality, but the same contributions may be considered highly undesirable under a different set of circumstances (see Table 3 ) as found in the cool- versus warm-climate wine regions.

\section{Loss of acidity and increase in $\mathrm{pH}$}

Depending on the initial $\mathrm{pH}$ of the must, the removal of L-malic acid via MLF can be either advantageous or detrimental to wine quality. In high-acid/low-pH wines typically found in the cool-climate regions, a decrease in excess L-malic acid is highly favourable for the production of acid-balanced wines (Boulton et al., 1996; Henick-Kling, 1995; Lonvaud-Funel, 1999). MLF usually leads to a reduction in final TA of 1 to $3 \mathrm{~g} / \mathrm{L}$ and an average increase in $\mathrm{pH}$ of 0.1 to 0.3 units in wine (Margalit, 1997). Subsequently, the rise in $\mathrm{pH}$ after MLF often promotes the precipitation of potassium bitartrate, leading to an additional reduction in TA (Beelman and Gallander, 1979; Ribéreau-Gayon et al., 2000). 
TABLE 3

Influence of LAB's metabolism on wine sensory profile.

\begin{tabular}{|c|c|c|}
\hline Bacterial strain & Advantage & Risk \\
\hline Selected $O . \propto n i$ & $\begin{array}{l}\text { - Reduction of total acidity } \\
\text { - Reduction of ketone and aldehyde compounds (reducing } \mathrm{SO}_{2} \text { requirement) } \\
\text { - Partial microbial stability } \\
\text { - Reduction of grassy and vegetative notes } \\
\text { - Increase in front-pallet volume } \\
\text { - More diacetyl level control } \\
\text { - Dominance over wild bacteria }\end{array}$ & $\begin{array}{l}\text { - Production of volatile acidity (especially under high pH con- } \\
\text { ditions, in presence of residual sugars and after L-malic acid } \\
\text { degradation) } \\
\text { - Loss of color } \\
\text { - Production of ethyl carbamate }\end{array}$ \\
\hline Spontaneous $O . \propto n i$ & $\begin{array}{l}\text { - Reduction of total acidity } \\
\text { - Reduction of ketone and aldehyde compounds (reducing } \mathrm{SO}_{2} \text { requirement) } \\
\text { - Partial microbial stability } \\
\text { - Reduction of grassy and vegetative notes } \\
\text { - Increase in front-pallet volume }\end{array}$ & $\begin{array}{l}\text { - Long lag phase involving an increase in the volatile acidity } \\
\text { depending on the pH } \\
\text { - Significant bacterial growth involving a high production of } \\
\text { diacetyl } \\
\text { - Production of spoilage aromas and flavours (mousy off- } \\
\text { flavour, sweat, sauerkraut) } \\
\text { - Reduction of esters (fruity characters) } \\
\text { - Loss of varietal aromas } \\
\text { - Color loss by direct action on polyphenols } \\
\text { - Production of biogenic amines } \\
\text { - Production of ethyl carbamate }\end{array}$ \\
\hline L. mesenteroides & - Reduction of total acidity & $\begin{array}{l}\text { - Production of viscous compounds (ropy wines) } \\
\text { - Production of spoilage aromas and flavours }\end{array}$ \\
\hline Lb. plantarum, Lb. casei & $\begin{array}{l}\text { - Reduction of total acidity in must or wine } \\
\text { - No production of acetic acid from sugar (hexose) }\end{array}$ & $\begin{array}{l}\text { - Sensitive to alcohol over } 5 \% \text { vol. } \\
\text { - Sluggish or stuck fermentation in high } \mathrm{pH} \text { wine at high cont- } \\
\text { amination levels } \\
\text { - Production of spoilage aromas and flavours ( } \mathrm{Lb} \text {. casei) }\end{array}$ \\
\hline $\begin{array}{l}\text { P. pentosacceus } \\
\text { P. damnosus }\end{array}$ & $\begin{array}{l}\text { - Reduction of total acidity in must or wine } \\
\text { - No production of acetic acid from sugar (hexose) }\end{array}$ & $\begin{array}{l}\text { - Production of viscous compounds (ropy wines) } \\
\text { - Production of biogenic amines } \\
\text { - Risk of sluggish or stuck fermentation at } \mathrm{pH}>3.5 \text {, with high } \\
\text { contamination levels } \\
\text { - Risks increase with the } \mathrm{pH} \text { value }\end{array}$ \\
\hline $\begin{array}{l}\text { Lb. brevis } \\
\text { Lb. hilgardii }\end{array}$ & - Reduction of total acidity in must or wine & $\begin{array}{l}\text { - Production of viscous compounds (ropy wines) } \\
\text { - Production of biogenic amines } \\
\text { - High production of ethyl carbamate } \\
\text { - Production of spoilage aromas and flavours } \\
\text { - Production of acetic acid }\end{array}$ \\
\hline Lb. kunkeei & & $\begin{array}{l}\text { - Strong competition with yeasts during the alcoholic fermen- } \\
\text { tation for nutrients } \\
\text { - Overproduction of acetic acid }\end{array}$ \\
\hline
\end{tabular}

The incidence of MLF in wine with an initial high $\mathrm{pH}$ (or low acidity), usually found in the warmer climatic regions, has the opposite impact on wine quality. MLF in these wines leads to an additional reduction in wine acidity and a subsequent increase in $\mathrm{pH}$ due to the degradation of L-malic acid, and results in undesirable "bland" wines that lack adequate acidity. Under these circumstances, the aesthetics of red wine is often negatively affected in terms of red colour intensity, with a potential loss of ca. $30 \%$ in red colour due to the shift in $\mathrm{pH}$ (Kunkee, 1967; Vetsch and Lüthi, 1964). Furthermore, the risk of spoilage by strains of lactobacilli and pediococci is enhanced in these elevated-pH wines.

\section{Microbial stability}

Winemakers have long believed that MLF leads to an increase in microbial stability due to the depletion of essential nutrients in wine and the fastidious growth requirements of $\mathrm{LAB}$, especially
O. oeni. This might be partly true for high-acid/low-pH wines, where the antimicrobial effect of low $\mathrm{pH}$ dominates in inhibiting the growth of spoilage bacteria after the first round of MLF. The apparent depletion of residual nutrients, which includes L-malic acid, citric acid, amino acids, nitrogen bases, vitamins and fermentable sugars left after alcoholic fermentation, prevents the growth of other spoilage bacteria. Furthermore, LAB produce antimicrobial compounds such as lactic acid and bacteriocins (Rammelsberg and Radler, 1990) that inhibit the growth of other related bacterial species (Henick-Kling, 1993). However, spoilage by strains of LAB is often encountered, especially if low concentrations of L-malic acid remain in the wine or the wines have high initial pH levels (Costello et al., 1983; Davis et al., 1986).

The benefit of increased microbial stability due to MLF is therefore also more applicable to the cool-climate viticultural 
regions where the low $\mathrm{pH}$ of wine remains an inhibitory factor after completion of MLF. Under these circumstances, complete removal of L-malic acid and citric acid during MLF, which serves as a relatively good nutritional resource for $O$. oeni, does minimise the risk of bacterial growth after bottling. In the warmer viticultural regions, the use of MLF is tolerated in most red and some white cultivars for the sole purpose of completely removing L-malic acid from the wine and contributing to the organoleptic profile of the wine. However, winemakers have to adjust the $\mathrm{pH}$ of the wine prior to MLF, usually with tartaric acid, to prevent spoilage by LAB and other bacteria.

\section{Wine sensory modifications.}

The role of MLF in improving the sensory complexity of wine is one of the more dubious benefits of MLF when compared to its role in deacidification and microbial stability of wine. Results from various chemical and sensorial studies have shown that numerous flavour-active substances are produced by LAB that are involved in the aroma changes of wine during malolactic fermentation. However, to date, only a few of these compounds and their biosyntheses have been identified (Moreno-Arrabis and Polo, 2005). The most convincing change in wine taste after MLF is the replacement of the strong "green" taste of L-malic acid with the less aggressive taste of lactic acid (Beelman and Gallander, 1979; Lonvaud-Funel, 1999). Removal of the sharp taste of excess L-malic acid is usually described in terms of the mouth feel and extended aftertaste of wine compared to non-MLF control wines (Davis et al., 1985; Henick-Kling, 1993; Henick-Kling et al., 1994; Malík, 1998). In general, wines that underwent MLF, particularly red wines, are often characterised by lower vegetative/herbaceous aromas, while the fruity and floral characters are also reduced due to the degradation of several esters and other flavour compounds (McDaniel et al., 1987; Laurent et al., 1994). Many other flavours such as 'buttery', 'lactic', 'nutty', 'oaky', 'yeasty' and 'sweaty' have been described in wines after MLF (Laurent et al., 1994).

The improvement of the front-palate volume and roundness in the mouth is not only due to the reduction in acidity of the wine. Certain LAB can produce metabolites that improve mouth feel either directly or by binding with bitter and astringent wine compounds. Specific metabolites synthesised during the metabolism of LAB, especially strains of $O$. oeni, have been identified as flavour compounds in wine and it is argued that these compounds play a role in improving the sensory complexity of wine (McDaniel et al., 1987; Rodriquez et al., 1990). These metabolites are synthesised in varying concentrations during MLF and include compounds such as acetaldehyde, 2,3-butanediol, acetic acid, acetoin, 2-butanol, and various other volatile esters (such as ethyl lactate, isoamyl acetate, ethyl caproate, diethyl succinate and ethyl acetate) (Meunier and Bott, 1979; Zeeman et al., 1982). Diacetyl, a volatile diketone and end product of citric acid metabolism by $\mathrm{LAB}$, is also produced during MLF, and is often perceived as a desirable buttery or nutty flavour when present in low concentrations (Bartowsky \& Henschke, 2004; Davis et al., 1985).

The exact sensory contribution of MLF in wine is extremely difficult to evaluate due to the intricate nature of the factors that play a role. The number of flavour compounds synthesised during MLF is greatly influenced by the initial wine $\mathrm{pH}$ and the fermentation temperature, which determines the rate of malolactic fer- mentation. When the rate of malolactic fermentation is high (high $\mathrm{pH}$ and temperature), the production of acetic acid is enhanced, while the production of diacetyl is favoured under low $\mathrm{pH}$ and temperature conditions. The flavour contribution by MLF in wine is further complicated by the large diversity of strains and species of LAB that are usually involved in MLF (see Table 2). For example, individual strains of $O$. oeni contribute different flavour changes to the wine during MLF (Henick-Kling et al., 1994; Zeeman et al., 1982).

The sensory changes incurred during malolactic fermentation are not always desirable in all wine styles and cultivars. Some delicate European white wines, such as Muscat, Riesling, Sauvignon Blanc and Gewürztraminer, are protected against natural MLF, since the LAB degrade many terpenes and other flavour molecules that diminish the varietal fruity-floral aromas revealed during alcoholic fermentation (Lonvaud-Funel, 1999 Radler, 1972). Furthermore, many of the metabolic products of LAB are usually perceived as off-flavours when produced at elevated levels. For example, the synthesis of diacetyl often masks the characteristics of white wines with heavy notes of butter or cheese that can be considered as offflavours (Martineau et al., 1995). Some strains of LAB, especially the lactobacilli, have the ability to degrade L-tartaric acid, which could lead to severe deficiencies in wine TA, a spoilage defined as tourne (Ribéreau-Gayon et al., 2000). Another type of off-flavour associated with lactobacilli, amertume, is caused by dehydration of glycerol to 3-hydroxypropionaldehyde, which is further reduced to 1,3-propanediol (Schutz and Radler, 1984). Bitterness is caused by a combination of acrolein derived from 3-hydroxypropionaldehyde to phenolic compounds (Rentscher and Tanner, 1951). Some Lactobacillus spp. sometimes contributes to a mousy taint due to nitrogen heterocycle compounds produced by the acylation of lysine and ornithine, as shown in Lactobacillus hilgardii by Costello et al. (2001).

\section{Health factors.}

The wholesomeness of wine is becoming an ever-increasingly important marketing tool in the wine trade. Winemakers are therefore steering clear of procedures that could tarnish the hygienic or health image of their wines, i.e. the excessive use of detrimental chemicals such as $\mathrm{SO}_{2}$. The synthesis of two undesirable compounds in wine during conventional malolactic fermentation, namely biogenic amines and ethyl carbamate, have led to a renewed interest in finding alternatives for bacterial wine deacidification (see Table 3).

\section{Biogenic amine production during $M L F$}

$\mathrm{LAB}$ are well known to produce biogenic amines during the process of fermentation of foods and beverages (Guerrini et al., 2002). Biogenic amines (e.g. histamine) are generated via the decarboxylation of naturally occurring amino acids (e.g. histidine) through substrate-specific enzymes (Ten Brink et al., 1990). The physiological role of this reaction in LAB is thought to ensure growth and survival in acidic conditions, since it increases the $\mathrm{pH}$. Although the biogenic amine content of fermented foods is usually higher than that found in wine, the presence of alcohol, $\mathrm{SO}_{2}$ and other biogenic amines has been shown to amplify the toxic effect of certain biogenic amines (Fernandes and Ferreira, 2000; Ibe et al., 1991; Silla Santos, 1996). For example, the presence of putrescine, the most prevalent amine in wine 
(Soufleros et al., 1998), is known to act as a potentiator of histamine toxicity in humans (Taylor, 1986).

The concentration of biogenic amines, especially histamine, tyramine and putrescine, in wine is higher after the completion of malolactic fermentation (Lonvaud-Funel and Joyeux, 1994; Radler and Fäth, 1991; Soufleros et al., 1998). The biogenic amine content of wine is dependent on the amino acid composition of the wine after alcoholic fermentation and the specific microflora present in wine, but more importantly on the ability of to decarboxylate amino acids. At elevated $\mathrm{pH}$ levels, biogenic amines are usually found at higher concentrations in wine due to easier growth and greater bacterial diversity (Lonvaud-Funel and Joyeux, 1994). Commercial cultures of malolactic bacteria are therefore selected not to produce high levels of biogenic amines.

\section{Ethyl carbamate $(E C)$ production during $M L F$}

Arginine, usually one of the most abundant amino acids in grape juice, is metabolised by yeasts to urea, which is released into wine when it accumulates in the yeast cell during or at the end of fermentation. Urea spontaneously reacts with the ethanol in wine to form EC, a naturally occurring compound present in all fermented foods and beverages. There is a general agreement that the presence of EC in wine is not desirable and must be maintained at as low a level as possible since it has been proven to be a carcinogen when administered at high dosages in animal tests (Azevedo et al., 2002; Liu and Pilone, 1998). Although, the main source of EC in wine is from the ethanolysis of urea synthesised during yeast metabolism, some strains of LAB can also produce precursors of EC. Most of the commercial O. oeni strains are able to break down arginine through the arginine deiminase pathway (ADI pathway), during which citrulline and carbamyl phosphate are excreted, and react with ethanol to produce ethyl carbamate (Liu et al., 1994).

\section{Control of malolactic fermentation}

Although malolactic fermentation is the most widely accepted deacidification method of wine, the bioconversion of L-malic acid to lactic acid is a difficult and time-consuming process that does not always proceed favourably under the typical conditions of wine. It can lead to spoilage of wine when it occurs after bottling and during storage of wine, especially in wines with $\mathrm{pH}$ values higher than 3.5. Malolactic fermentation tends to occur spontaneously in low-acid wines, where it is least wanted, and the outcome of the modified flavours is unpredictable due the proliferation of some Lactobacillus and Pediococcus spp. (Henick-Kling and Edinger, 1994; Zeeman et al., 1982). However, the occurrence of spontaneous malolactic fermentation in wineries is unpredictable and irregular (Boulton et al., 1996; Davis et al., 1986; Wibowo et al., 1985) and may take place immediately after alcoholic fermentation or only weeks or months later, or only after bottling if the wine has not been correctly stabilised (Henick-Kling, 1995). The control of LAB is crucial during winemaking, since their presence at the end of alcoholic fermentation is beneficial, but detrimental to wine quality during maturation, which is solely based on spontaneous chemical reactions that result in the modification of wine aroma and colour (LonvaudFunel, 1999).

Numerous physicochemical, chemical and biological conditions in wine influence the development of MLF (Britz and
Tracey, 1990; Vaillant et al., 1995). The most important factors that influence the onset and completion of MLF are the initial wine composition, fermentation and storage temperature, as well as interactions between $\mathrm{LAB}$ and other wine-related microorganisms. Even with a complete understanding of MLF and the factors that play a role in the successful development of MLF, wine remains a hostile environment to LAB. Numerous advances have therefore been made in the field of MLF starter culture production as well as some other alternative technologies for the successful development of MLF in wine. Winemakers can intentionally induce MLF in "resistant" wines by blending them with wine that is undergoing, or which has already completed, MLF (Castino et al., 1975). Based on their survival abilities, specific strains of $O$. oeni have been selected for the commercial production of liquid, lyophilised or freeze-dried starter cultures for the inoculation of wine to ensure successful MLF (Henick-Kling, 1995). Although no official data are available on the prevalence of induced MLF in commercial wine production, roughly $75 \%$ of all red wines and $40 \%$ of white wines usually undergo induced MLF (Maicas, 2001; Ough, 1992).

Starter cultures of LAB are selected according to strict criteria (Davis et al., 1985; Vaillant et al., 1995). The strains must have a fast growth rate under winemaking conditions and should not produce any off-flavours or off-odours. Malolactic strains are further selected for their tolerance to low $\mathrm{pH}(\mathrm{pH}<3.0)$, high ethanol levels of up to $14 \%(\mathrm{v} / \mathrm{v})$ and non-lysogenic characteristics after phage infection (Drici-Cachon et al., 1996). Lastly, the strains should have good growth characteristics and be suitable for drying to make their commercial production economically viable in terms of type and cost of culturing media (Kunkee, 1991). Strains of LAB can also be selected based on their inability to produce biogenic amines such as histamine. With the help of PCR, DNA probes and activity assays, strains of LAB can now be screened for the presence of the amino acid decarboxylase genes (Costantini et al., 2006; Le Jeune et al., 1995; LonvaudFunel, 2001; Marcobal et al., 2004;).

The availability of active bacterial starter cultures to induce MLF has certainly contributed to many successful applications of this secondary 'fermentation'. However, the completion of malolactic fermentation cannot be guaranteed and starter culture delay or failure is not unusual under certain conditions (Beelman and Gallander, 1979; Guerzoni et al., 1995). Reactivation conditions of freeze-dried starter cultures before inoculation into wine also play a role in the successful completion of malolactic fermentation (Nault et al., 1995), since direct inoculation of starter cultures in wine leads to loss of viability (Davis et al., 1985; Nielsen et al., 1996).

\section{Alternative technologies to develop MLF in wine}

Persistent problems with bacterial starter cultures have driven the search for other alternatives to ensure rapid and reliable procession of MLF in wine. The use of bioreactors with free or immobilised strains of LAB, as well as cell-free bioreactors with immobilised malolactic enzyme and cofactors, have been evaluated for application in wine deacidification (Gao and Fleet, 1994; Maicas, 2001; Spettoli et al., 1982, 1984, 1987). The major problems associated with these technologies involve the degree of difficulty to prepare matrixes, the use of unacceptable chemicals in wine and the unsuccessful scaling-up of free or immobilised 
high-density cell bioreactors for industrial application. Furthermore, cell-free bioreactors using only immobilised enzymes have thus far not been completely effective in converting L-malic acid to lactic acid.

Genetic engineering of strains of $S$. cerevisiae to degrade L-malic acid is an important alternative that has a significant potential for the wine industry. Molecular biologists have attempted to transfer the malolactic activity of LAB into $S$. cerevisiae to enable the yeast to execute the alcoholic and malolactic fermentation simultaneously. Williams et al. (1984) expressed the gene for malolactic activity of $L$. delbrueckii in $S$. cerevisiae, but the recombinant strain of $S$. cerevisiae only managed to metabolise $1 \%$ and $1.5 \%(\mathrm{w} / \mathrm{v})$ L-malic acid in synthetic media and grape must, respectively. The L-malic acid assimilating activity from $O$. oeni was also cloned and expressed in $E$. coli and yeast, but due to DNA stability problems the research was not further pursued (Lautensach and Subden, 1984). Nearly a decade later, the mleS genes of $L$. lactis and $O$. oeni were subcloned under control of the strong, constitutive 3-phosphoglycerate kinase $(P G K 1)$ promoter and terminator sequence of $S$. cerevisi$a e$ and successfully expressed in a laboratory strain of $S$. cerevisiae (Ansanay et al., 1993; Denayrolles et al., 1994; 1995; Labarre et al., 1996). Both the E. coli and S. cerevisiae strains containing the mleS gene produced malolactic activity, but they were still unable to efficiently degrade L-malic acid under winemaking conditions.

The main limitation of the above attempts to genetically engineer $S$. cerevisiae with a malolactic pathway is ascribed to the slow, inefficient uptake of L-malic acid via simple diffusion by the yeast (Grobler et al., 1995). Expression of the malolactic gene (mleS) in yeast was therefore not adequate to improve $S$. cerevisiae's ability to degrade L-malic acid (Ansanay et al., 1996). Pre-empting the requirement of a $S$. cerevisiae with a functional malate transport mechanism, cloning and characterisation of the malate permease gene ( $\mathrm{mael}$ ) and the malic enzyme gene (mae2) of $S$. pombe were undertaken (Grobler et al., 1995; Subden et al., 1998; Viljoen et al., 1994). Co-expression of the malate transporter gene (mael) of $S$. pombe and the malolactic enzyme gene of L. lactis and $O$. oeni in a laboratory strain of $S$. cerevisiae resulted in a recombinant strain of $S$. cerevisiae that actively transported L-malic acid and efficiently converted it to lactic acid (Volschenk et al., 1997a, 1997b; 2004). The recombinant S. cerevisiae strain was able to perform alcoholic and malolactic fermentation simultaneously, rendering malolactic fermentation with $\mathrm{LAB}$ redundant.

The malate transporter gene (mael) of $S$. pombe and the malolactic enzyme gene of $O$. oeni were subsequently stably integrated in the genomes of an industrial Prise de Mousse wine yeast strain in a pioneering endeavour to develop a commercially available wine yeast strain with the ability to degrade L-malic acid during alcoholic fermentation (Husnik et al., 2006). The ML01 yeast has received Generally Regarded As Safe (GRAS) status from the US FDA and has been commercialised in the USA and Moldavia. The application of the malolactic wine yeast ML01 has resulted in efficient malolactic fermentation, lower volatile acidity and improved colour properties of wine (Husnik, unpublished). Ethyl carbamate was lower in wines produced with ML01 compared to wines produced with the parental strain S92 and LAB.

\section{CONCLUDING REMARKS}

Wine acidity and $\mathrm{pH}$ play a crucial role in the winemaking process and the final organoleptic quality and shelf-life of wine. L-Tartaric acid and L-malic are the major grape acids, contributing to more than $90 \%$ of the TA in wine (Beelman and Gallander, 1979; Gao and Fleet, 1994; Henick-Kling, 1993; Radler, 1993). The production of premium wines depends on the optimal adjustment of wine acidity in relation to the other wine components to obtain a balanced wine with an optimum flavour and colour profile. In low acid wines, acidulating agents such as L-tartaric acid or D/L-malic acid are routinely added prior to fermentation to increase the TA of must to ensure an optimal acid:sugar ratio in grape must (Beelman and Gallander, 1979; Boulton et al., 1996). The traditional method to deacidify wine involves the conversion of L-malic acid to L-lactic acid and $\mathrm{CO}_{2}$ during malolactic fermentation by strains of $O$. oeni. However, due to inherent problems associated with malolactic fermentation and its unsuitability in some fruityfloral cultivars, alternative biological methods for the deacidification of wine will be of great benefit to the wine industry. Deacidification of wine with a malo-degrading yeast strain may eliminate the use of bacterial starter cultures for malolactic fermentation, which in turn will reduce the risk of the production of hazardous compounds such as biogenic amines and ethyl carbamate. Furthermore, it should decrease delays in cellar operations due to the simultaneous completion of alcoholic fermentation and deacidification, which in turn will minimise the risk of spoilage by oxidation and the proliferation of spoilage microorganisms.

\section{LITERATURE CITED}

Ansanay, V., Dequin, S., Blondin, B. \& Barre, P., 1993. Cloning, sequence and expression of the gene encoding the malolactic enzyme from Lactococcus lactis. FEBS Lett. 332, 74-80.

Ansanay, V., Dequin, S., Camarasa, C., Schaeffer, V., Grivet, J., Blondin, B., Salmon, J. \& Barre, P., 1996. Malolactic fermentation by engineered Saccharomyces cerevisiae as compared with engineered Schizosaccharomyces pombe. Yeast 12, 215-225.

Archer, E. \& Strauss, H.C., 1989. Effect of shading on the performance of Vitis vinifera L. cv. Cabernet Sauvignon. S. Afr. J. Enol. Vitic. 10, 74-77.

Azevedo, Z., Couto, J.A. \& Hogg, T., 2002. Citrulline as the main precursor of ethyl carbamate in model fortified wines inoculated with Lactobacillus hilgardii: a marker of the levels in a spoiled fortified wine. Lett. Appl. Microbiol. 34, 32-36.

Bartowsky, E.J. \& Henschke, P.A., 2004. The 'buttery' attribute of wine-diacetyldesirability, spoilage and beyond. Int. J. Food Microbiol. 96, 235-252.

Beelman, R.B. \& Gallander, J.F., 1979. Wine deacidification. Adv. Food Res. 25, $1-53$.

Blanke, M.M. \& Lenz, F., 1989. Fruit photosynthesis. Plant Cell Environ. 12, 3146.

Bony, M., Bidard, F., Camarasa, C., Ansanay, V., Dulau, L., Barre, P. \& Dequin, S., 1997. Metabolic analysis of $S$. cerevisiae engineered for malolactic fermentation. FEBS Lett. 410, 452-456.

Boulton, R.B., Singleton, V.L., Bisson, L.F. \& Kunkee, R.E., 1996. Principles and Practices of Winemaking. Chapman and Hall, New York. pp. 102-181; 244-273; 352-378.

Britz, T.J. \& Tracey, R.P., 1990. The combination effect of $\mathrm{pH}, \mathrm{SO}_{2}$, ethanol and temperature on the growth of Leuconostoc oenos. J. Appl. Bacteriol. 68, 23-31.

Burns, D.J.W. \& Noble, A.C., 1985. Evaluation of the separate contributions of viscosity and sweetness of sucrose to perceived viscosity, sweetness and bitterness of Vermouth. J. Texture Stud. 16, 365-389.

Capucho, I. \& San Romao, M.V., 1994. Effect of ethanol and fatty acids on malolactic activity of Leuconostoc oenos. Appl. Microbiol. Biotechnol. 42, 391-395. 
Carr, F.J., Chill, D. \& Maida, N., 2002. The lactic acid bacteria: A literature survey. Crit. Rev. Microbiol. 28, 281-370.

Castino, M., Usseglio-Tomasset, L. \& Gandini, A., 1975. Factors which affect the spontaneous initiation of malolactic fermentation in wines. The possibility of transmission by inoculation and its effect on organoleptic properties. In: J.G. Carr, C.V. Cutting, and G.C. Whiting (eds.). Lactic acid bacteria in beverages and food. Academic Press, New York. pp. 139-148.

Charoenchai, C., Fleet, G. \& Henscke, P.A., 1998. Effects of temperature, pH and sugar concentration on the growth rates and cell biomass of wine yeasts. Am. J. Enol. Vitic., 49, 283-288.

Costantini, A., Cersosimo, M., Del Prete, V. \& Garcia-Moruno, E., 2006. Production of biogenic amines by lactic acid bacteria: screening by PCR, thinlayer chromatography, and high-performance liquid chromatography of strains isolated from wine and must. J. Food Protec. 69, 391-396.

Coombe, B.G., 1992. Research on development and ripening of the grape berry. Am. J. Enol. Vitic. 43, 101-110.

Costello, P., Lee, T.H. \& Henschke, P.A. 2001. Ability of lactic acid bacteria to produce N-heterocycles causing mousy off-flavour in wine. Aust. J. Grape and Wine Research, 7, 160-167.

Costello, P.J., Morrison, G.J., Lee, T.H. \& Fleet, G.H., 1983. Numbers and species of lactic acid bacteria in wines during vinification. Food Technol. Austr. 35, $14-18$

Crippen, D. \& Morrison, J.C., 1986. The effect of sun exposure on the compositional development of Cabernet Sauvignon berries. Am. J. Enol. Vitic. 37, 235242 .

Darias-Martin, J.J., Oscar, R., Diaz, E. \& Lamuela-Raventós, R.M., 2000. Effect of skin contact on the antioxidant phenolics in white wine. Food Chem. 71, 483487

Davies, C. \& Robinson, S.P., 2000. Differential screening indicates a dramatic change in mRNA profiles during grape berry ripening: cloning and characterization of cDNAs encoding putative cell wall and stress response proteins. Plant. Physiol. 122, 803-812

Davis, C.R., Wibowo, D.J., Eschenbruch, R., Lee, T.H. \& Fleet, G.H., 1985. Practical implications of malolactic fermentation: A review. Am. J. Enol. Vitic. 36, 290-301.

Davis, C.R., Wibowo, D.J., Lee, T.H. \& Fleet, G.H., 1986. Growth and metabolism of lactic acid bacteria during and after malolactic fermentation of wines at different pH. Appl. Environ. Microbiol. 51, 539-545.

Denayrolles, M., Aigle, M. \& Lonvaud-Funel, A., 1994. Cloning and sequence analysis of the gene encoding the Lactococcus lactis malolactic enzyme: relationships with malic enzymes. FEMS Micriobiol. Lett. 116, 79-86.

Denayrolles, M., Aigle, M. \& Lonvaud-Funel, A., 1995. Functional expression in Saccharomyces cerevisiae of the Lactococcus lactis mleS gene encoding the malolactic enzyme. FEMS Microbiol. Lett. 125, 3744.

Diakou, P., Svanella, L., Raymond, P., Gaudillère, J. \& Moing, A., 2000. Phosphoenolpyruvate carboxylase during grape berry development: protein level, enzyme activity and regulation. Aust. J. Plant Physiol. 27, 221-229.

Dicks, L.M.T. \& van Vuuren, H.J.J., 1988. Identification and physiological characteristics of hetero-fermentative strains of Lactobacillus from South African red wines. J. Appl. Bacteriol. 64, 505-513.

Dicks, L.M.T., van Vuuren, H.J.J. \& Dellaglio, F., 1990. Taxonomy of Leuconostoc species, particularly Leuconostoc oenos, as revealed by numerical analysis of total soluble cell protein patterns, DNA-base composition, and DNADNA hybridizations. Int. J. Syst. Bacteriol. 40, 83-91.

Drici-Cachon, Z., Guzzo, J., Cavin, J.-F. \& Diviès, C., 1996. Acid tolerance in Leuconostoc oenos. Isolation and characterization of an acid-resistant mutant. Appl. Microbiol. Biotechnol. 44, 785-789.

Du Plessis, H.W., Dicks, L.M.T., Pretorius, I.S., Lambrechts, M.G. \& Du Toit, M. 2004. Identification of lactic acid bacteria isolated from South African brandy base wines. Int. J. Food Microbiol. 91, 19- 29.

Fernandes, J.O. \& Ferreira, M.A., 2000. Combined ion-pair extraction and gas chromatography-mass spectrometry for the simultaneous determination of diamines, polyamines and aromatic amines in port wine and grape juice. J. Chromatogr. A. 886, 183-195.

Ferreira, B., Hory, C., Bard, M.H., Taisant, C., Olsson, A. \& le Fur, Y., 1995. Effects of skin contact and settling on the level of the C18:2, C18:3 fatty acids and
$\mathrm{C}_{6}$ compounds in Burgundy Chardonnay musts and wines. Food Qual. Pref. 6, 3541 .

Fillion, L., Ageorges, A., Picaud, S., Coutos-Thévenot, P., Lemoine, R., Romieu, C. \& Delrot, S., 1999. Cloning and expression of a hexose transporter gene expressed during the ripening of grape berry. Plant. Physiol. 120, 1083-1093.

Fischer, U. \& Noble, A.C., 1994. The effect of ethanol, catechin concentration, and $\mathrm{pH}$ on sourness and bitterness of wine. Am. J. Enol. Vitic. 45, 6-10.

Fleet, G.H., Lafon-Lafoucade, S. \& Ribéreau-Gayon, P., 1984. Evolution of yeasts and lactic acid bacteria during fermentation and storage of Bordeaux wines. Appl. Environ. Microbiol. 48, 1034-1038.

Fugelsang, K.C., 1997. In: Wine Microbiology. Chapman and Hall, New York.

Gallander, J.F., 1977. Deacidification of Eastern table wines with Schizosaccharomyces pombe. Am. J. Enol. Vitic. 28, 65-68.

Gao, C. \& Fleet, G.H., 1994. The degradation of malic acid by high-density cell suspensions of Leuconostoc oenos. J. Appl. Bacteriol. 76, 632-637.

Garvie, E.I. \& Farrow, J.A., 1980. The differentiation of Leoconostoc oenos from non-acidophilic species of Leuconostoc, and the identification of five strains from the American Type Culture Collection. Am. J. Enol. Vitic. 31, 154-157.

Grobler, J., Bauer, F., Subden, R.E. \& van Vuuren, H.J.J., 1995. The mae1 gene of Schizosaccharomyces pombe encodes a permease for malate and other $\mathrm{C}_{4}$ dicarboxylic acids. Yeast 11, 1485-1491.

Guerrini, S., Mangani, S., Granchi, L. \& Vincenzini, M., 2002. Biogenic amine production by Oenococcus oeni. Curr. Microbiol. 44, 374-378.

Guerzoni, M.E., Sinigaglia, M., Gardini, F., Ferruzzi, M. \& Torriani, S., 1995. Effects of $\mathrm{pH}$, temperature, ethanol, and malate concentration on Lactobacillus plantarum and Leuconostoc oenos: Modeling of the malolactic activity. Am. J. Enol. Vitic. 46, 368-374.

Hashizume, T. \& Mori, E.E.M., 1990. Evaluation of apple cultivars for cider making. Colet. Inst. Technol. Aliment. 20, 73-82.

Henick-Kling, T., 1993. Malolactic fermentation. In: G.H. Fleet (ed.). Wine Microbiology and Biotechnology. Harwood Academic Publishers, Switzerland. pp. 289-326.

Henick-Kling, T., 1995. Control of malolactic fermentation in wine: energetics, flavour modification and methods of starter culture preparation. J. Appl. Bacteriol. S79, 29S-37S

Henick-Kling, T., Acree, T.E., Krieger, S.A., Laurent, M.H. \& Edinger, W.D., 1994. Modification of wine flavour by malolactic fermentation. Wine East. March/April, 8-15; 29-30.

Henick-Kling, T. \& Edinger, W.D., 1994. Malolactic starter cultures for wine. In: T. Henick-Kling (ed.). Proc. 23rd Ann. New York Wine Ind. Works, New York State Agricultural Experiment Station, Cornell University, Geneva. pp. 107-115.

Husnik, J.I., Volschenk, H., Bauer, J., Colavizza, D., Luo, Z. \& van Vuuren, H.J.J., 2006. Metabolic engineering of malolactic wine yeast. 2006. Metabol. Eng. 8, 315-323.

Ibe, A., Saito, K., Nakazato, M., Kikuchi, Y., Fujinuma, K. \& Nishima, T., 1991. Quantitative determination of amines in wine by liquid chromatography. J. Assoc. Off. Anal. Chem. 74, 695-698.

Jackson, D.I., 2001. Climate-monographs in cool climate viticulture 2. Daphne Brasell Associates Ltd., Wellington, New Zealand

Jackson, D. \& Schuster, D., 1997. The grape and its growth. In: The Production of Grapes \& Wine in Cool Climates. Lincoln University Press, Canterbury, New Zealand. pp. 50-54.

Kanellis A.K. \& Roubelakis-Angelakis, K.A., 1996. Grape. In: G.B. Seymour, J.E. Taylor, G.A. Tucker (eds.). Biochemistry of Fruit Ripening. Chapman and Hall, London. pp. 189-234.

Kliewer, W. M., Howarth, L. \& Omori, M., 1967. Concentration of tartaric acid and malic acid and their salts in Vitis vinifera grapes. Am. J. Enol.Vitic. 18, 42-54.

Kluba, R.M. \& Beelman, R.B., 1975. Influence of amelioration on the major acid components of musts and wine from four French-hybrid grape cultivars. Am. J. Enol. Vitic. 26, 18-24.

Kunkee, R.E., 1967. Control of malolactic fermentation induced by Leoconostoc citrovorum. Am. J. Enol. Vitic. 18, 71-77. 
Kunkee, R.E., 1991. Some roles of malic acid in the malolactic fermentation in wine making. FEMS Microbiol. Rev. 88, 55-72.

Labarre, C., Guzzo, J., Cavin, J.-F. \& Diviès, C., 1996. Cloning and characterization of the genes encoding the malolactic enzyme and the malate permease of Leuconostoc oenos. Appl. Environ. Microbiol. 62, 1274-1282.

Lafon-Lafourcade, S., Lonvaul-Funel, A. \& Carré, E., 1983. Lactic acid bacteria of wines: stimulation of growth and malolactic fermentation. Antonie Van Leeuwenhoek. 49, 349-352.

Laurent, M.H., Henick-Kling, T. \& Acree, T.E., 1994. Changes in the aroma and odor of Chardonnay due to malolactic fermentation. Wein Wissensch. 49, 3-10.

Lautensach, A. \& Subden, R.E., 1984. Cloning of malic acid assimilating activity from Leuconostoc oenos in E. coli. Microbios. 39, 29-39.

Lavee, S. \& Nir, G., 1986. Grape. In: S.P. Monselise (ed.). CRC handbook of fruit set and development. CRC Press, Boca Raton, Florida, USA. pp. 167-191.

Le Jeune, C., Lonvaul-Funel, A., Ten Brink, B., Hofstra, H. \& van der Vossen, J.M., 1995. Development of a detection system for histidine decarboxylation lactic acid bacteria based on DNA probes, PCR and activity test. J. Appl. Bacteriol. 78, 316-326.

Liu S.Q. \& Pilone, G.J., 1998. A review: arginine metabolism in wine lactic acid bacteria and its practical significance. J. Appl. Microbiol. 84, 315-327.

Liu, S.Q., Prichard, G.C., Hardman, M.J. \& Pilone, G.C., 1994. Citrulline production and ethyl carbamate (urethane) precursor formation from arginine degradation by wine lactic acid bacteria Leuconostoc oenos and Lactobacillus bucheneri. Am. J. Enol. Vitic. 45, 235-242.

Lonvaud-Funel, A., 1999. Lactic acid bacteria in the quality improvement and depreciation of wine. Antonie van Leeuwenhoek. 76, 317-331.

Lonvaud-Funel, A., 2001. Biogenic amines in wines: role of lactic acid bacteria. FEMS Microbiol. Lett. 199, 9-13.

Lonvaud-Funel, A. \& Joyeux, A., 1994. Histamine production by wine lactic acid bacteria: isolation of a histamine-producing strain of Leuconostoc oenos. J. Appl. Bacteriol. 77, 401-407.

Maicas, S., 2001. The use of alternative technologies to develop malolactic fermentation in wine. Appl. Microbiol. Biotechnol. 56, 35-39.

Malík, F., 1998. Bases of enology. In: M. Berovic (Ed.). Bioprocess engineering course. National Institute of Chemistry, Ljubljana. pp. 182-206.

Marcobal, A., de las Rivas, B., Moreno-Arribas, M.V. \& Muñoz, R., 2004. Identification of the ornithine decarboxylase gene in the putrescine-producer Oenococcus oeni BIFI-83. FEMS Microbiol. Lett. 239, 213-220.

Margalit, Y., 1997. In: J. Crum (ed.). Concepts in Wine Chemistry. Wine Appreciation Guild Ltd., San Fransisco, USA. pp. 16-18; 76-82.

Martin, N. \& Revel, G., 1999. Sensory evaluation: scientific bases and enological application. J. Int. des Sciences de la Vigne et du Vin, Special Issue: Wine tasting, June, 81-93.

Martineau, B., Henick-Kling, T. \& Acree, T., 1995. Reassessment of the influence of malolactic fermentation on the concentration of diacetyl in wines. Am. J. Enol. Vitic. 46, 385-388.

McDaniel, M., Henderson, L.A., Watson, B.T. \& Heatherbell, D., 1987. Sensory panel training and screening for descriptive analysis of the aroma of Pinot Noir wine fermented by several strains of malolactic bacteria. J. Sens. Stud. 2, 149-167.

Meunier, J.M. \& Bott, E.W., 1979. Das berhalten vershiender Aromastoffe in Bergunder-weinen im verlauf des biologischen Säureabbaus. Chem. Mikrobiol. Technol. Lebensm. 6, 92-95.

Moreno-Arrabis, M.V. \& Polo, M.C., 2005. Winemaking biochemistry and microbiology: Current knowledge and future trends. Crit. Rev. Food Sci. Nutr. 45, 265286.

Morrison, J.C. \& Noble, A.C., 1990. The effects of leaf and cluster shading on the composition of Cabernet Sauvignon grapes and on fruit and wine sensory properties. Am. J. Enol. Vitic. 41, 193-200.

Narendranath, N.V., Hynes, H.S., Thomas, K.C. \& Ingledew, W.M., 1997. Effects of lactobacilli on yeast-catalyzed ethanol fermentations. Appl. Environ. Microbiol. 63, 4158-4163.

Nault, I., Gerbaux, V., Larpent, J.P. \& Vayssier, Y., 1995. Influence of pre-culture conditions on the ability of Leuconostoc oenos to conduct malolactic fermentation in wine. Am. J. Enol. Vitic. 46, 357-362.
Nielsen, J.C., Prahl, C. \& Lonvaul-Funel, A., 1996. Malolactic fermentation in wine by direct inoculation with freeze-dried Leuconostoc oenos cultures. Am. J. Enol. Vitic. 47, 42-48

Noble, A.C., 1998. Why do wines taste bitter and feel astringent? In: A.L. Waterhouse and S.E. Ebeler (eds.). Chemistry of wine flavour. Oxford University Press, Washington, DC, USA. pp. 156-165.

Or, E., Baybik, J., Sadka, A \& Ogrodovitch, A., 2000. Fermentative metabolism in grape berries: isolation and characterization of pyruvate decarboxylase cDNA and analysis of its expression throughout berry development. Plant Sci. 156, 151158.

Ough, C.S., 1992. Winemaking basics. Haworth Press, Binghampton, New York.

Pilone, G.J. \& Kunkee, R.E., 1970. Carbonic acid from decarboxylation by "malic" enzyme in lactic acid bacteria. J. Bacteriol. 103, 404-409.

Pool, R. \& Henick-Kling, T., 1991. Production methods in Champagne. New York State Agricultural Experiment Station, Cornell University, New York.

Pratelli, R., Lacombe, B., Torregrosa, L., Gaymard, F., Romieu, C., Thibaud, J. \& Sentenac, H., 2002. A grapevine gene encoding a guard cell $\mathrm{K}^{+}$channel displays developmental regulation in the grapevine berry. Plant Physiol. 128, 564-577.

Pretorius, I.S., 2000. Tailoring wine yeast for the new millennium: novel approaches to the ancient art of winemaking. Yeast 16, 675-729.

Radler, F., 1972. Problems in malolactic fermentation. Weinberg. Keller 19, 357370.

Radler, F., 1993. Yeasts-metabolism of organic acids. In: G.H. Fleet (ed.). Wine Microbiology and Biotechnology. Harwood Academic Publishers, Switzerland. pp. $165-182$.

Radler, F. \& Fäth, K.P., 1991. Histamine and other biogenic amines in wine. In: J.M Rantz (ed.). Proc. Int. Symp. Nitrogen Grape Wine. , Am. Soc. Enol. Vitic., Davis, California. pp. 185-195

Rammelsberg, M. \& Radler, F., 1990. Antibacterial polypeptides of Lactobacillus species. J. Appl. Bacteriol. 69, 177-184.

Rentscher, H. \& Tanner, H. 1951. Das bitterwerden der rotweine. Mitt.Gebeite Lebensmittelunster 42,463-475.

Ribéreau-Gayon, P., Dubourdieu, D., Donéche B. \& Lonvaud, A., 2000. Handbook of Enology. Wiley \& Sons, Ltd., Chichester, England.

Rodriquez, S.B., Amberg, E. \& Thornton, R.J., 1990. Malolactic fermentation in Chardonnay: Growth and sensory effects of commercial cultures of Leoconostoc oenos. J. Appl. Bacteriol. 68, 139-144.

Ruffner, H.P., 1982. Metabolism of tartaric and malic acids in Vitis: a review - part B. Vitis. 21, 346-358.

Ruffner, H.P. \& Kliewer, W.M., 1975. Phosphoenolpyruvate carboxykinase activity in grape berries. Plant Physiol. 56, 67-71.

Ruffner, H.P., Possner, D., Brem, S. \& Rast, D.M., 1984. The physiological role of malic enzyme in grape ripening. Planta 160, 444-448.

Schutz, H. \& Radler. F. 1984. Anaerobic reduction of glycerol to propoanediol 1,3 by Lactobacillus brevis and Lactobacillus buchneri. Syst. Appl. Microbiol. 5, 169-178.

Silla Santos, M.H., 1996. Biogenic amines: their importance in foods. Int. J. Food Microbiol. 29, 213-231.

Smart, R.E., 1985. Principles of grapevine canopy microclimate manipulation with implications of yield and quality - a review. Am. J. Enol. Vitic. 36, 230-239.

Soufleros, E., Barrios, M.L. \& Bertrand, A., 1998. Correlation between the content of biogenic amines and other wine compounds. Am. J. Enol. Vitic. 49, 266278 .

Spettoli, P., Bottacin, A., Nuti, M.P. \& Zamorani, A., 1982. Immobilization of Leuconostoc oenos ML34 in calcium alginate gels and its application to wine technology. Am. J. Enol. Vitic. 33, 1-5.

Spettoli, P., Nuti, M.P., Crapici, A. \& Zamorani, A., 1987. Technological improvement of malolactic fermentation in wine by immobilized microbial cells in a continuous flow reactor. Ann. N.Y. Aca. Sci. 501, 385-389.

Spettoli, P., Nuti, M.P. \& Zamorani, A., 1984. Properties of malolactic activity purified from Leuconostoc oenos ML34 by affinity chromatography. Appl. Environ. Microbiol. 48, 900-901. 
Strauss, C.R., Gooley, P.R., Wilson, B. \& Williams, P.J., 1987. Development of precursors of $\mathrm{C}_{13}$-norisoprenoid flavorants in Riesling grapes. Am. J. Enol. Vitic. $38,23$.

Subden, R.E., Krizus, A., Osothsilp, C., Viljoen, M. \& van Vuuren, H.J.J., 1998. Mutational analysis of malate pathways in Schizosaccharomyces pombe. Food Res. Int. 31, 37-42.

Taylor, S.L., 1986. Histamine food poisoning: toxicology and clinical aspects. Crit. Rev. Toxicol. 17, 91-128.

Ten Brink, B., Damink, C., Joosten H.M.L.J. \& Huis in’t Veld, J.H.J., 1990. Occurrence and formation of biologically active amines in foods. Int. J. Food Microbiol. 11, 73-84.

Terrier, N., Sauvage, F.X., Ageorges, A. \& Romieu, C., 2001. Changes in acidity and in proton transport at the tonoplast of grape berries during development. Planta 213, 20-28.

Vaillant, H., Formisyn, P. \& Gerbaux, V., 1995. Malolactic fermentation of wine: study of the influence of some physio-chemical factors by experimental design assays. J. Appl. Bacteriol. 79, 640-650.

Vannier, A., Brun, O.X. \& Feinberg, M.H., 1999. Application of sensory analysis to champagne wine characterisation and discrimination. Food Qual. Pref. 10, 101107.

Van Vuuren, H.J.J. \& Dicks, L.M.T., 1993. Leuconostoc oenos: a review. Am. J. Enol. Vitic. 44, 99-112.

Vetsch, U. \& Lüthi, H., 1964. Decolorisation of red wines during biological decomposition of acids. Mitt. Geb. Lebensm. Hyg. 55, 93-98.

Viljoen, M., Subden, R.E., Krizus, A. \& van Vuuren, H.J.J., 1994. Molecular analysis of the malic enzyme gene (mae2) of the yeast Schizosaccharomyces pombe. Yeast 10, 613-624.
Volschenk, H., Viljoen, M., Grobler, J., Bauer, F., Lonvaud-Funel, A., Denayrolles, M., Subden, R.E. \& van Vuuren, H.J.J., 1997a. Malolactic fermentation in grape musts by a genetically engineered strain of Saccharomyces cerevisiae. Am. J. Enol. Vitic. 48, 193-196.

Volschenk, H., Viljoen, M., Grobler, J., Petzold, B., Bauer, F., Subden, R.E., Young, R.A., Lonvaud, A., Denayrolles, M. \& van Vuuren, H.J.J., 1997b. Engineering pathways for malate degradation in Saccharomyces cerevisiae. Nature Biotech. 15, 253-257.

Volschenk, H., Viljoen-Bloom, M., van Staden, J., Husnik, J. \& van Vuuren, H.J.J., 2004. Genetic engineering of an industrial strain of Saccharomyces cerevisiae for malic acid degradation via an efficient malo-ethanolic pathway. S. Afr. J. Enol. Vitic. 25, 63-73.

Wibowo, D., Eschenbruch, R., Davis, C.R., Fleet, G.H. \& Lee, T.H., 1985. Occurrence and growth of lactic acid bacteria in wine: A review. Am. J. Enol. Vitic. 36, 302-313.

Williams, S.A., Hodges, R.A., Strike, T.L., Snow, R. \& Kunkee, R.E., 1984. Cloning the gene for the malolactic fermentation of wine from Lactobacillus delbrueckii in Escherichia coli and yeasts. Appl. Environ. Microbiol. 47, 288-293.

Winterhalter, P., Sefton, M.A. \& Williams, P.J., 1990. Volatile $\mathrm{C}_{13}$ norisoprenoid compounds in Riesling wine are generated from multiple precursors. J. Agric. Food Chem. 41, 277-283.

Zeeman, W., Snyman, J.P. \& van Wyk, C.J., 1982. The influence of yeast strain and malolactic fermentation on some volatile bouquet substances and on the quality of table wines. In: A.D. Webb (ed.). Proc. Univ. of Calif., Grape Wine Cent. Symp. University of California, Davis. pp. 79-90.

Zoecklein, B.W., Fugelsang, K.C., Gump, B.H. \& Nury, F.S., 1995. Wine Analysis and Production. Chapmann \& Hall, New York. 